\title{
New distribution record of Coelosis biloba Linnaeus, 1767 (Scarabaeidae: Dynastinae: Oryctini) in Córdoba, northern Colombia
}

\author{
Roger Ayazo ${ }^{1,3}$, Leidys Murillo-Ramos ${ }^{2} \&$ Yuleimis Martínez-Caballero \\ ${ }^{1}$ Universidad de Córdoba, Carrera 6 No. 76-103 Montería, Córdoba, Colombia. \\ ${ }^{2}$ Universidad de Sucre, Carrera 28 N ${ }^{\circ}$ 5-267 Barrio Puerta Roja Sincelejo, Sucre, Colombia \\ ${ }^{3}$ Corresponding author. E-mail: ayazob@gmail.com
}

\begin{abstract}
We report Coelosis biloba for the rainforest of the buffer zone of Paramillo Natural National Park, south of Córdoba. The specimen was collected at night, in a mist net to catch bats. This represents a new location for the distribution of this species in Córdoba and the sixth record for the northern coast of Colombia. The few records of this species in northern Colombia compared to other regions of the country are due to lack of studies in biodiversity and the absence of entomological collections at universities on the Caribbean coast.
\end{abstract}

Key words. Scarabaeidae, rainforest, Paramillo Natural National Park

The genus Coelosis Hope is composed of seven species and is widely distributed in the new world (ENDRÖDI 1976). Two species have been reported in Colombia; C. bicornis (Leske, 1779) and C. biloba (Linnaeus, 1767) (SANABRIA et al. 2012). Coelosis biloba is the most widely distributed species in the genus, occurring from central México to southern Argentina (ENDRÖDI 1985; RATCLIFFE et al. 2013). The third instar larva and, male and female pupae were described from exemplars collected from Colombia and México (Pardo-Locarno et al. 2006). Adults are easy to collect in light traps, and may also be captured in both Malaise traps and flight interception traps (RATCLIFFE 2003). Larvae and adults have been found in the nest chambers of Atta sp. (Morón et al. 1997; PARDOLOCARNo et al. 2006; RATCLIFFe et al. 2013). In the Brazilian Amazon, this species is associated with degraded ecosystems, agricultural areas, semi-humid ombrophilous forests, savannahs, and flooded areas (GASCA-ÁLvAREZ et al. 2008). In Colombia $C$. biloba has been collected from sea level to $2600 \mathrm{~m}$ elevation although most of the occurrences recorded are concentrated in the Andean region (SANABRIA et al. 2012). Records of C. biloba in Colombia are from localities in the departments of Amazonas, Arauca, Boyacá, Caquetá, Casanare, Cauca, Cundinamarca, Huila, Meta, Nariño, Putumayo, Risaralda, Santander, Tolima, Valle del Cauca and Magdalena (Gasca-Álvarez \& Amat-García 2010; Sanabria et al. 2012). Additional localities from the departments of Antioquia, Cesar, Chocó, Córdoba and Quindío are also recorded in a study by PARDo-Locarno et al. (2006); however, specific collection data from these additional sites are not provided by the authors. Here we report a male of C. biloba for the rainforest of the buffer zone of Paramillo Natural National Park, northern Colombia and compiled records published by SANABRIa et al. (2012) and PARdo-Locarno et al. (2004) (Fig. 1).

The specimen was captured in a mist net in a nocturnal sampling session to capture bats in a tropical rainforest in the buffer zone in the Paramillo National Natural Park (upper basin of the Sinú River). The mist net was set at the border between a forest fragment and an open rice field. The locality data are: Colombia, Córdoba, Tierralta, Corregimiento Palmira, Vereda "La Plumilla", Finca El Oriente, $08^{\circ} 03^{\prime} 12.5^{\prime \prime} \mathrm{N}$, $076^{\circ} 02^{\prime} 28.5^{\prime \prime} \mathrm{W}, 20-\mathrm{V}-2015$. Bh-t., elevation $341 \mathrm{~m}$, Y. Martínez collector (Fig. 1). The specimen is deposited in the zoological collection of the Universidad de Córdoba, Colombia (CZUC).

The species can be recognized by the mandibles tridentate, clypeus usually narrow with the apex bidentate, head of male with a horn and two pronotal projections, elytra with distinct rows of punctures and tridentate protibiae (GASCA-ÁlvareZ \& Amat-García 2010; Sanabria et al. 2012) (Fig. 2). In Colombia two species, C. biloba and C. bicornis, have been recorded. Coelosis biloba can be distinguished from C. bicornis by its bifurcate dorsally flattened horn on the posterior half of the pronotum in males (SANABRIA et al. 2012).

The records of $C$. biloba for northern Colombia are scarce when compared to the number of records for the rest of the country. This new record complements the distribution of this species in Colombia and represents the sixth record for the north coast. The Caribbean region of Colombia is one of the least represented in the distribution of this species; only five localities in three of the seven departments that comprise it have been recorded. This region represents about $12 \%$ of the territory of Colombia and has elevations from sea level to 5775 m (HERNÁNDEZ 1992). This gradient includes the localities in which this species has been recorded (SANABRIA et al. 2012) and therefore records of this species in this area of the country could be more frequent. However, due to lack of studies in biodiversity in this region compared to others (i.e., Andean region) and the lack of organized zoological collections, 


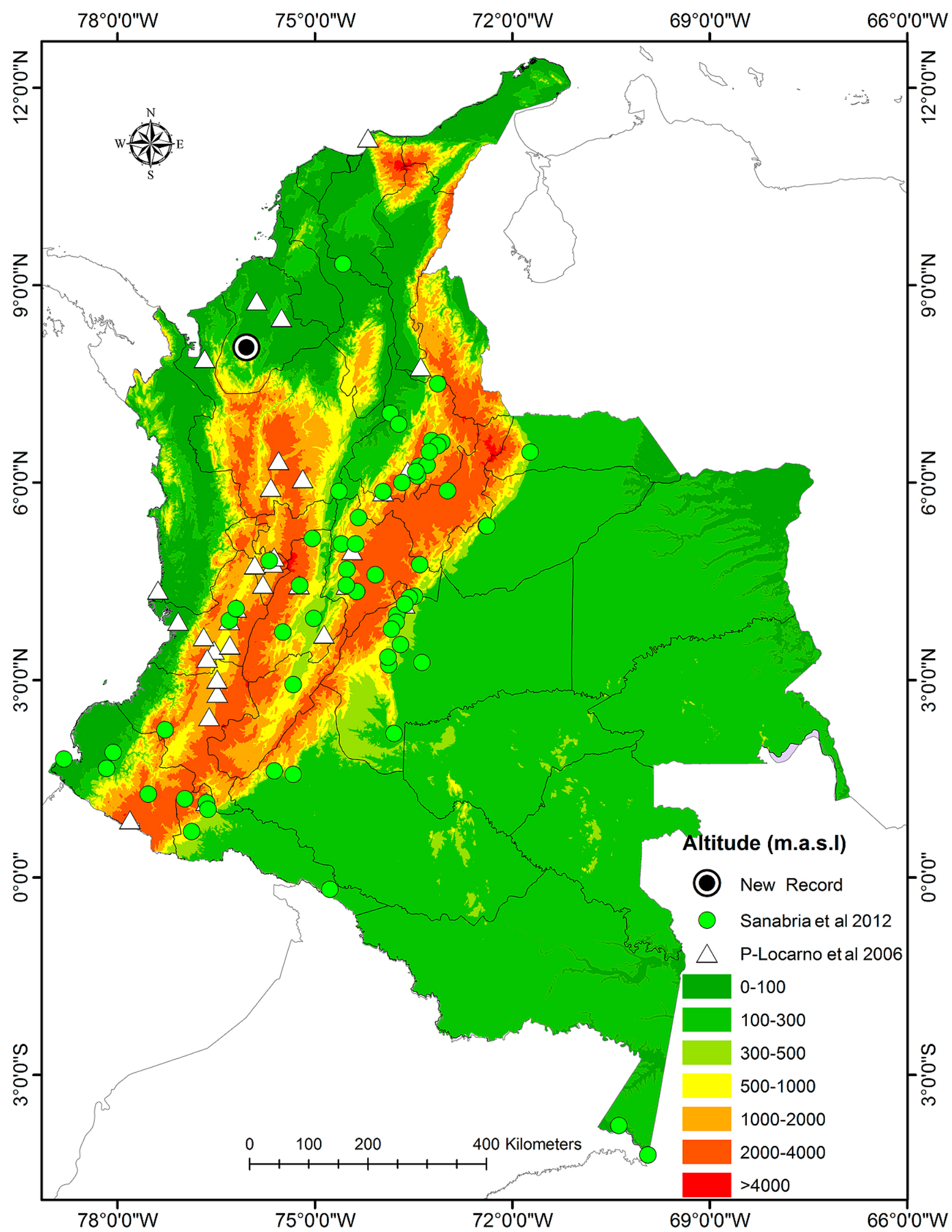

Figure 1. Distribution of Coelosis biloba in Colombia. Black dot surrounded by white $=$ new record in Córdoba, northern Colombia; green dots $=$ records compiled in SANABRIA et al. (2012); White triangles = records in PARDO-LOCARNO et al. (2006). 


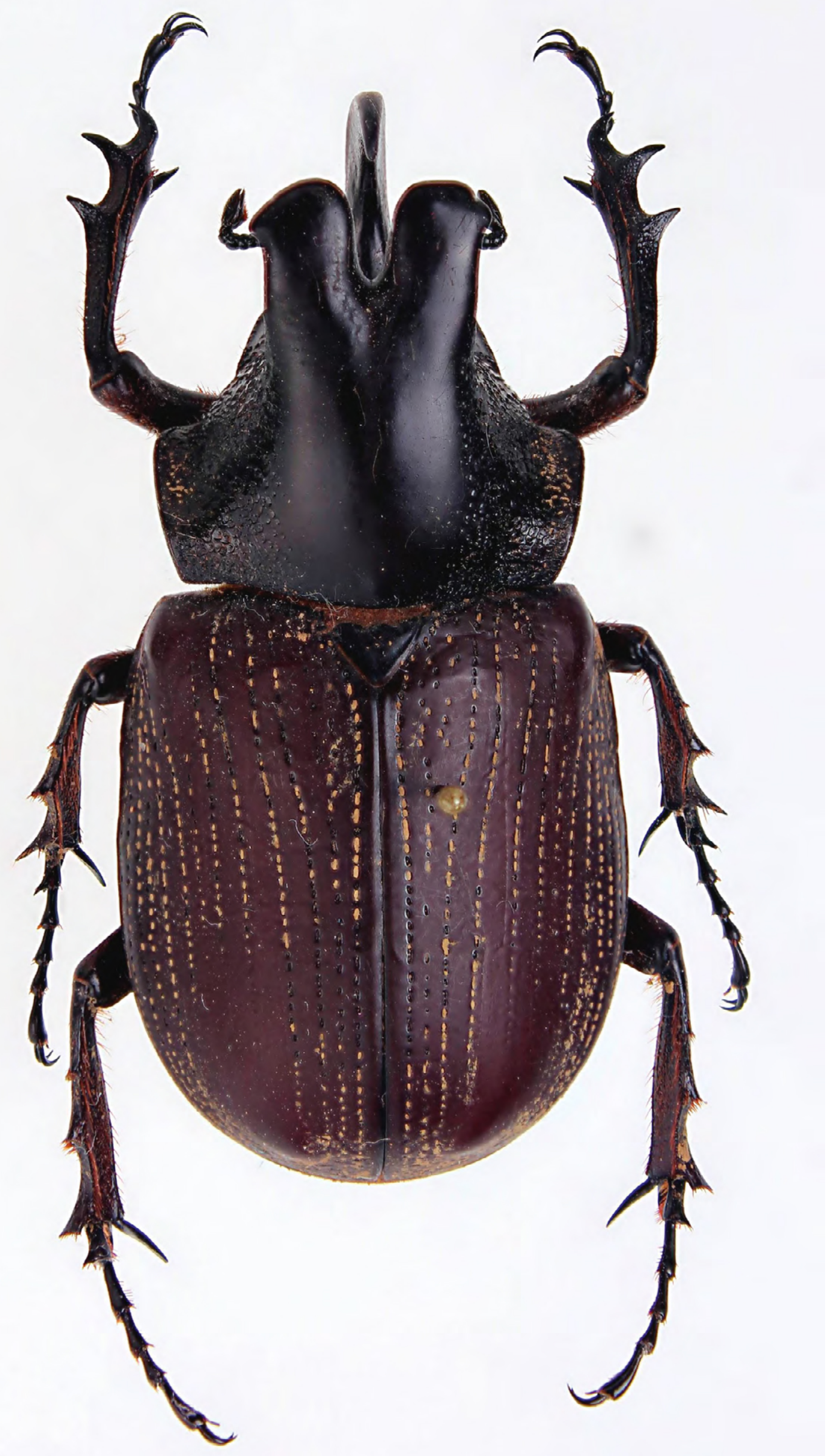

Figure 2. Male of Coelosis biloba from Córdoba, Colombia. 
especially entomological, from the Colombian Caribbean in universities or other institutions have restricted the documentation of the distribution of many species of phytophagous beetles (Pleurosticti) in the north of the country. According PARdo-Locarno et al. (2006) in Córdoba C. biloba has been recorded in two municipalities of the middle basin of the Sinú River (Montería \& Pueblo Nuevo). No specific collection data are given for these records. Besides, these municipalities are in the dry tropical forest zone as classified by HoLDRIDGE (1967) as well as the other locations recorded for the Caribbean coast of Colombia. Here we report a male from a new locality and a new habitat (tropical rainforest) in the south of Córdoba. Greater efforts in other areas in Colombia other than the center of the country to minimize bias in the distribution of this and other Colombian species are required.

\section{ACKNOWLEDGEMENTS}

We thank Milena López and Orly Vargas for collecting the specimen.

\section{LITERATURE CITED}

ENDRÖDI, S. 1976. Monographie der Dynastinae 5. Tribus: Oryctini (die Arten von Amerika) (Coleoptera: Melolonthinae). Folia Entomologica Hungarica 29: 9-174.

ENDRÖDI, S. 1985. The Dynastinae of the world. Dordrecht: W. Junk. $800 \mathrm{pp}$.

Gasca-Álvarez, H.J., C. DA Fonseca \& B. Ratcliffe. 2008. Synopsis of the Oryctini (Coleoptera: Scarabaeidae: Dynastinae) from the Brazilian Amazon. Insecta Mundi 0061: 1-62.

Gasca-Álvarez, H.J. \& G. Amat-García. 2010. Synopsis and key to the genera of dynastinae (Coleoptera, Scarabaeoidea, Scarabaeidae) of Colombia. ZooKeys 34: 153-192. https://doi.org/10.3897/ zookeys.34.309
HernándeZ, J. 1992. Caracterización geográfica de Colombia; pp. 45-55, in: G. HalfFter (ed.). La diversidad biológica de Iberoamérica I. México: Acta Zoológica Mexicana, Volumen especial.

Holdridge, L. 1967. Life zone ecology. San José: Tropical Science Center. 206 pp.

LesKe, N. 1779. Anfangsründe der Naturgeschichte. Erste Teil. 1. Algemeine Natur- und Tiergeschichte. Leipzig: S. L. Crusius. 560 pp.

Linnaeus, C. 1767. Systema naturæ, Tom. I. Pars II. Editio duodecima reformata. Stockholm: Salvius. 1327 pp.

Morón, M., B. Ratcliffe \& C. Deloya. 1997. Atlas de los escarabajos de México (Coleoptera: Lamellicornia). Vol. 1. México: Comisión Nacional para el Conocimiento y Uso de la Biodiversidad (CONABIO) y Sociedad Mexicana de Entomología. 280 pp.

Pardo-Locarno, L., M. Morón \& A. Gaigl. 2006. Los estados inmaduros de Coelosis biloba (Coleoptera: Melolonthidae: Dynastinae) y notas sobre su biología. Revista Mexicana de Biodiversidad 77: 215-224.

Ratcliffe, B., R. Cave \& E. Cano. 2013. the dynastine scarab beetles of Mexico, Guatemala, and Belize (Coleoptera: Scarabaeidae: Dynastinae). Bulletin of the University of Nebraska State Museum 27: 1-666.

Ratcliffe, B. 2003. The Dynastinae Scarab Beetles of Costa Rica and Panama. Bulletin of the University of Nebraska State Museum 16: 1-506.

Sanabria-García, R., H. Gasca-Álvarez \& G. Amat-García. 2012. Sinopsis de la tribu Oryctini (Coleoptera: Scarabaeinae: Dynastinae) de Colombia. Insecta Mundi 0276: 1-64.

Authors' contributions. YM collected the data, RA and LM wrote the text, and RA made the map.

Received: 15 June 2016

Accepted: 6 April 2017

Academic editor: Tiago K. Krolow 